\title{
Moving beyond the mousetrap: current and emerging humanized mouse and rat models for investigating prevention and cure strategies against HIV infection and associated pathologies
}

Yash Agarwall ${ }^{1 \dagger}$, Cole Beatty ${ }^{1 \dagger}$, Shivkumar Biradar ${ }^{1 \dagger}$, Isabella Castronova ${ }^{1 \dagger}$, Sara Ho ${ }^{1 \dagger}$, Kevin Melody ${ }^{2+}$ and Moses Turkle Bility ${ }^{1 *+}$ (D)

\begin{abstract}
The development of safe and effective combination antiretroviral therapies for human immunodeficiency virus (HIV) infection over the past several decades has significantly reduced HIV-associated morbidity and mortality. Additionally, antiretroviral drugs have provided an effective means of protection against HIV transmission. Despite these advances, significant limitations exist; namely, the inability to eliminate HIV reservoirs, the inability to reverse lymphoid tissues damage, and the lack of an effective vaccine for preventing HIV transmission. Evaluation of the safety and efficacy of therapeutics and vaccines for eliminating HIV reservoirs and preventing HIV transmission requires robust in vivo models. Since HIV is a human-specific pathogen, that targets hematopoietic lineage cells and lymphoid tissues, in vivo animal models for HIV-host interactions require incorporation of human hematopoietic lineage cells and lymphoid tissues. In this review, we will discuss the construction of mouse models with human lymphoid tissues and/or hematopoietic lineage cells, termed, human immune system (HIS)-humanized mice. These HIS-humanized mouse models can support the development of functional human innate and adaptive immune cells, along with primary (thymus) and secondary (spleen) lymphoid tissues. We will discuss applications of HIS-humanized mouse models in evaluating the safety and efficacy of therapeutics against HIV reservoirs and associated immunopathology, and delineate the human immune response elicited by candidate HIV vaccines. In addition to focusing on how these HIS-humanized mouse models have already furthered our understanding of HIV and contributed to HIV therapeutics development, we discuss how emerging HIS-humanized rat models could address the limitations of HIS-mouse models.
\end{abstract}

Keywords: Humanized mouse and rat models, Modeling HIV infection and reservoir, Modeling human anti-HIV immune response, In vivo models for HIV cure, Animal models for HIV vaccines

*Correspondence: mtbility@pitt.edu

${ }^{\dagger}$ Yash Agarwal, Cole Beatty, Shivkumar Biradar, Isabella Castronova, Sara Ho, Kevin Melody, Moses Turkle Bility contributed equally to the work

${ }^{1}$ Department of Infectious Diseases and Microbiology, Graduate School of Public Health, University of Pittsburgh, Pittsburgh, PA, USA

Full list of author information is available at the end of the article

\section{Background}

Despite combination antiretroviral therapy (cART)mediated suppression of human immunodeficiency virus (HIV) replication and promotion of immune reconstitution in patients, HIV-associated morbidity persists and is associated with the latent reservoir, unresolved immune abnormalities, and fibrosis in lymphoid organs [1]. 
Additionally, HIV transmission remains endemic across the globe, and development of a functional cure and/or an effective vaccine will be required to end this epidemic [2]. HIV is a human specific pathogen; thus, animal models for evaluating the safety and efficacy of therapeutics and vaccines directly against HIV requires the incorporation of human lymphoid tissues and/or hematopoietic lineage cells. Such mouse models exist, and are termed, human immune system (HIS)-humanized mice [3, 4]. To construct HIS-humanized mice, immunodeficient mice are myoablated to eradicate residual mouse bone marrow stem cells, and then engrafted with human peripheral blood mononuclear cells (PBMCs) or human hematopoietic stem cells (HSC) with or without transplantation of lymphoid tissues, such as thymus and/or spleen [5]. Over a period of a few weeks to months, transplanted mice develop human immune cells, and reconstitution is confirmed by flow cytometry [5] (Fig. 1). HIS-humanized mice can then be employed in studies investigating HIV prevention or cure strategies [5]. In this review, we will discuss the myriad of approaches for developing HIShumanized mouse models, and their applications in HIV therapeutics and vaccine development studies, along with their limitations. Finally, we will discuss the potential of an emerging HIS-humanized rat model, which has a longer lifespan and greater physiological similarity to humans compared to mice, designed to enable longitudinal studies in evaluating therapeutics against HIV reservoirs and vaccine-induced immunity $[6,7]$.

\section{Humanized mice that incorporate human immune cells}

\section{Peripheral blood lymphocytes (PBL)-humanized mouse model}

Human $\mathrm{CD}^{+}{ }^{+} \mathrm{T}$ cells are the major target for HIV infection; thus, a mouse model with human $\mathrm{CD} 4^{+} \mathrm{T}$ cells provides a platform for modeling HIV/AIDS. Various immunodeficient mouse models lacking mature $\mathrm{T}$, B, [8] and NK cells, along with defects in macrophage phagocytic function [9] support robust reconstitution of human $\mathrm{CD} 4+\mathrm{T}$ cells and other lymphocytes (e.g. CD8 $+\mathrm{T}$ cells) following transplantation of human PBMCs or CD4+ T cells. Such cells can be transplanted via intravenous (IV) or intraperitoneal (IP) injection into myoablated, immunodeficient juvenile mice (6-8 weeks old) at a dose of $5-10 \times 10^{\wedge} 6$ cell per mouse, to generate peripheral blood lymphocyte (PBL)-humanized mice. Human $\mathrm{CD} 4+\mathrm{T}$ cells are readily detectable in the blood

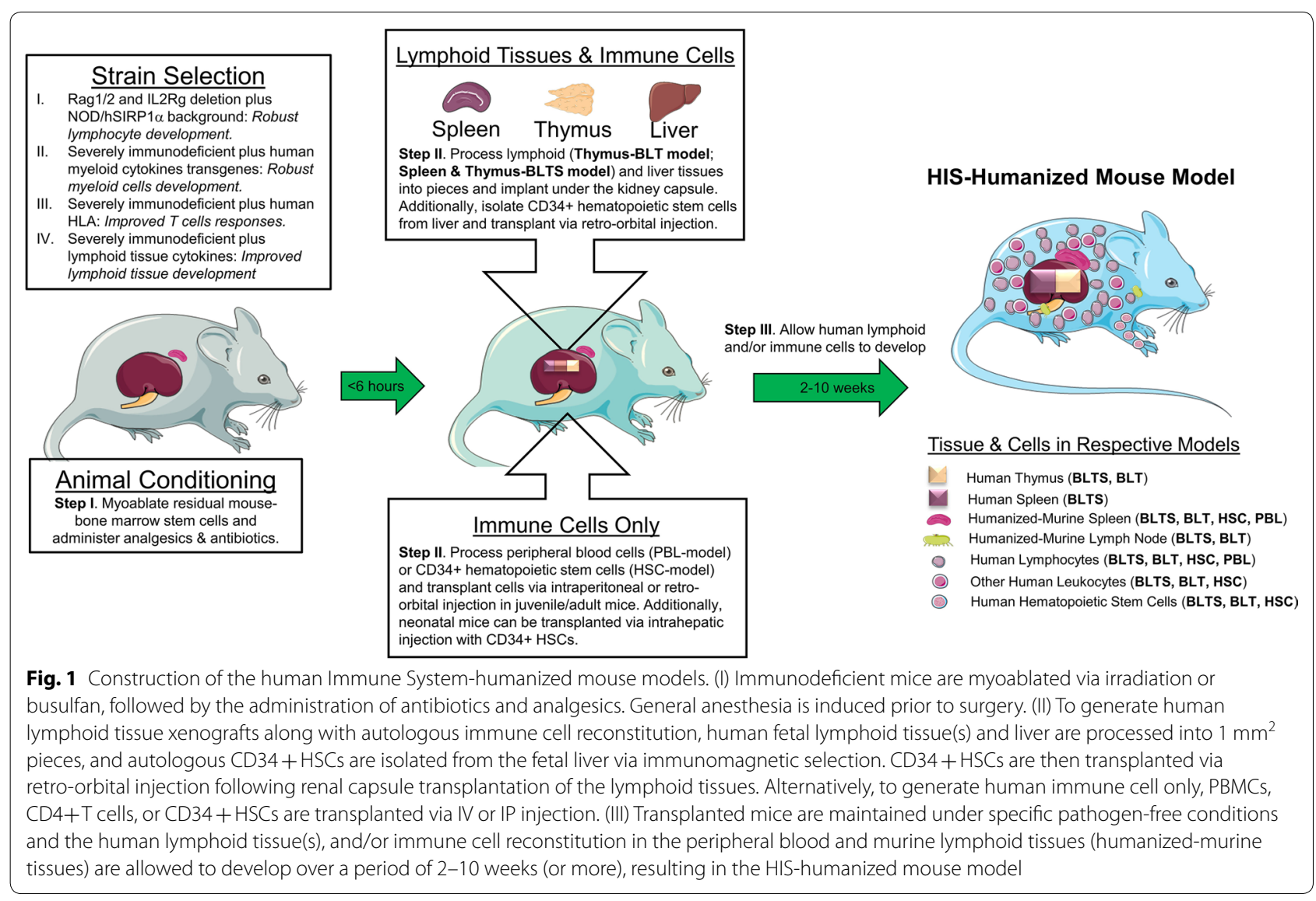


at 4 weeks post-transplantation $[9,10]$, hence providing a humanized mouse model that can be generated in a relatively short period. The PBL-humanized mouse model supports HIV replication and provides a means of evaluating the efficacy of direct-acting therapeutics (e.g. antivirals drugs, antibodies) geared towards preventing HIV transmission [11] and controlling HIV replication [9]. Additionally, PBL-humanized mouse models constructed using PBMCs from HIV-infected individuals with undetectable viral load can be employed as an in vivo assay (mouse-quantitative viral outgrowth assay) for evaluating the eradication of the HIV reservoir in said individuals $[12,13]$. A major limitation of this model is the rapid development of graft-versus-host (GvHD) disease within 6-7 weeks following transplantation of lymphocytes, thus significantly restricting the experimental window [14]. Additionally, the PBL-humanized mouse model does not incorporate human macrophages, which are a major HIV reservoir in various organs, including the brain $[9,15]$. However, modification of the PBL-humanized mouse model via transplantation of HIV-infected monocyte-derived macrophages in the brain supports HIV infection and pathogenesis in the brain [15].

\section{Hematopoietic stem cells (HSC)-humanized mouse model}

In order to generate a de novo human immune system and reconstitute a broader spectrum of human immune cells in HIS-humanized mice, myoablated, immunodeficient mice are transplanted with human CD34+HSCs via intrahepatic or intracardiac injection in neonatal mice $[10,16]$ or IV injection in juvenile/adult mice $[16,17]$. These HSCs can be obtained from a myriad of sources, including fetal liver tissue $[17,18]$ and neonatal cord blood cells $[4,16,19]$. Human immune reconstitution in the HSC-humanized mouse model requires 10-12 weeks to develop [20]. Various hematopoietic lineages, including $\mathrm{T}$ cells, monocytes/macrophages, $\mathrm{B}$ cells and dendritic cells are developed in the blood and other tissues (e.g., spleen, liver, brain) [20]. Moreover, the HSC-humanized mouse model generates a naïve human immune system, which negates confounding factors associated with prior pathogen exposure [16, 21]. The HSC-humanized mouse model supports HIV infection, $\mathrm{CD} 4+\mathrm{T}$ cell depletion, chronic immune activation and limited anti-HIV $\mathrm{T}$ and $\mathrm{B}$ cell immune responses [4]. A major advantage of the HSC-humanized mouse model over the PBL-humanized mouse model is the delayed and reduced incidence of GvHD, which provides the opportunity for long-term modeling of HIV infection and replication [9]. The HSC-humanized mouse model provides a means of evaluating the efficacy and safety of directacting therapeutics (e.g. antivirals drugs, antibodies) and immune-modulatory agents (e.g. pDC modulators
[22]) geared towards preventing HIV transmission, controlling HIV replication, and ameliorating $\mathrm{CD} 4+\mathrm{T}$ cell depletion and chronic immune activation [4]. The HSChumanized mouse model supports HIV transmission via the IV (along with IP) route [18]; however, conflicting reports exist for the mucosal route of transmission $[23,24]$. Additionally, the reconstituted human $\mathrm{T}$ cells are educated in the mouse thymic epithelium, thus limiting antigen-specific responses [25]. This limitation of $\mathrm{T}$ cell education in the murine thymic epithelium has been partially overcome by the construction human leukocyte antigen (HLA) class I transgenic-immunodeficient mice to support robust $\mathrm{T}$ cell development of HLA-matched HSC transplants [26]. Moreover, lymph nodes and spleen are poorly reconstituted, including a limited development of human B and myeloid cells in the white and red pulps of the spleen [27]. Several modifications have been made to the HSC model to address these limitations. Li et al. constructed an immunodeficient mouse model that incorporated a lymphoid tissue-stromal cytokine transgene (i.e. thymic-stromal-cell-derived lymphopoietin) and demonstrated improved lymph node development in HSC-humanized mice [27]. Additionally, studies have demonstrated enhanced human B and myeloid cell development in murine secondary lymphoid tissues via transgenic expression of critical cytokines (i.e. IL6; IL3, GM-CSF and SCF) for B and myeloid cell maturation [28-30]. Although incorporation of requisite human transgenes in HIS-humanized mice has been successful in demonstrating improved development of immune cells, often the resultant lineage is skewed, as the transgene expression is not synchronized for physiological expression and supporting stromal cells and other essential cytokines are absent [28-30].

\section{Humanized mice that incorporate human immune cells and lymphoid tissues}

Bone marrow-liver-thymus (BLT)-humanized mouse model

Another strategy for improving human immune cell development in HIS-humanized mouse models is to implant human lymphoid tissues containing the requisite microenvironment for supporting robust immune cell development. To facilitate human $\mathrm{T}$ cell education and associated function, human thymic tissues are incorporated in HIS-humanized mice, and termed, Bone marrow-liver-thymus (BLT)-humanized mice [31, 32] (Fig. 2). BLT-humanized mice have served as a key animal model for HIV research for over a decade and are a cost-effective alternative to the surrogate, simian immunodeficiency virus (SIV)-non-human primate (NHP) models. The BLT-humanized mouse model is generated by surgically transplanting myoablated, immunodeficient 

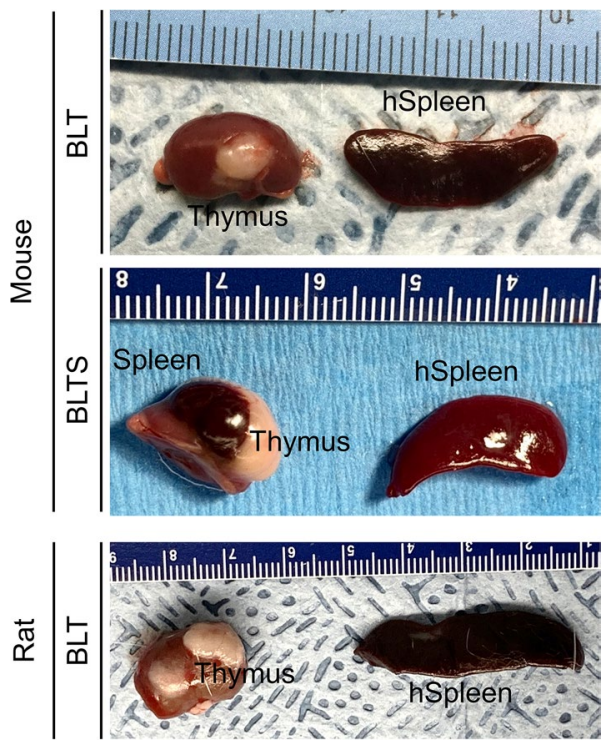

Fig. 2 Current and emerging HIS-humanized animal models. To construct HIS-humanized mice and rats, immunodeficient mice and rats are myoablated, followed by engraftment of human lymphoid tissues (thymus with or without human spleen) under the kidney capsule, along with injection of autologous human CD34+ hematopoietic stem cells. In representative images, we show the engrafted human lymphoid tissues (human thymus xenograft-thymus, white tissue; human spleen xenograft-Spleen, dark brown tissue and the reconstituted rodent-spleen (humanized spleen-hSpleen). Note: mouse and rat organs are not at the same scale

mice with fetal human liver and thymus tissues, followed by IV injection of autologous CD34 ${ }^{+}$HSCs [31, 33, 34]. Transplanted mice require 10-12 weeks for systemic reconstitution of human cells post-transplantation [31, 33, 34]. The most widely utilized strain for constructing BLT mice is the NOD-Prkdc ${ }^{\text {sid }} I L 2 \operatorname{rg}^{\text {Tm1Wjl }}$ (NSG) $[21,32]$, which is readily available from Jackson Laboratory. BLT-humanized mice can also be constructed using comparable immunodeficient mouse strains, such

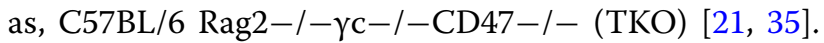
The key benefit of the BLT-humanized mouse model over PBL- and HSC-humanized mouse models is the presence of human thymic microenvironment, which facilitates $T$ cell education in an autologous human tissue that contains the requisite stromal cells (as well as cytokines and factors, presumably at physiological levels) [21]. BLT-humanized mice have systemic tissue reconstitution with human immune cells, including in mucosal tissues, which enables mucosal transmission [36-43] and recapitulates the main route of HIV transmission in humans [36-44]. Other hallmarks of HIV infection and replication in BLT-humanized mice include robust $\mathrm{T}$ cell depletion $[36,42]$, central nervous system infiltration $[45,46]$, immune response [35, 47-50], and latency [51-53]. The BLT-humanized mouse model is a robust platform for evaluating HIV prevention and cure strategies, including antiretroviral therapy, pre-exposure prophylaxis (PrEP), latency reversing agents (LRA), vaccination, proviral excision, and $\mathrm{T}$ cell engineering (Table 1 ).

Despite significant advances gained from the BLThumanized mouse model, the system does have some disadvantages. Construction of BLT-humanized mice requires advanced surgical expertise and extensive experience; therefore, these animals are constructed predominantly by specialized core facilities. Additionally, BLT-humanized mice are prone to GvHD, which limits the experimental window these animals can be utilized to approximately 6 months post-engraftment $[54,55]$. However, BLT-humanized mice constructed with a C57BL/6 immunodeficient background are resistant to GvHD [35, 53]. Another disadvantage involves the use of human fetal tissues in constructing the model; these tissues are not readily available. Furthermore, a typical human fetal thymus and autologous fetal liver-derived HSCs can only support the construction of 15-25 BLT-humanized mice. The limited availability of said human fetal tissues creates logistical and operational constraints. Recently, a novel BLT-like humanized mouse model has been developed using non-autologous human cord blood-derived HSCs and human neonatal/pediatric thymus, which enable investigators to construct $>1000$ BLT-like humanized mice using cryopreserved thymus tissues and readily available cord blood-derived HSCs [96]. Recent studies demonstrate that these BLT-like humanized mice develop human immune cells, support HIV infection and replication, and exhibit anti-HIV immune response (unpublished data from Elie Haddad, Chloé Colas, et al., at the CanCure 5th Annual General Meeting-2019, Poster Session, in Montreal, Canada). Despite systemic immune cell reconstitution and HIV-specific immune responses, both neonatal/pediatric tissue- and fetal tissue-derived BLT-humanized mouse models BLT mice do not develop a complete human immune system. The current widely used immunodeficient mouse models possess an IL-2 receptor $\gamma$ chain deletion [97-100]. As a result, mouse lymphoid organs do not fully develop in such models, [21] and the loss of lymphoid tissue microenvironment impairs the ability of BLT-humanized mice to develop a robust humoral immune response, as immunoglobulins are skewed towards IgM or weak IgG response [35, 49, 99, 101-103]. Constructing BLT-humanized mice using immunodeficient mouse models with requisite human transgenic factors/cytokines, may optimize human B cell development and overcome the limitations of humoral immune response in the model $[28,104,105]$. An alternative strategy, which is consistent with the BLT-model 
Table 1 Studies utilizing BLT-humanized mice for evaluating HIV-therapeutics

\begin{tabular}{|c|c|c|}
\hline Strategy & Therapeutic agent(s) & Reference(s) \\
\hline \multirow[t]{14}{*}{ Antiviral therapy } & $d C A$ & {$[45,56]$} \\
\hline & EFdA & {$[57]$} \\
\hline & RAL & {$[45]$} \\
\hline & PD-1 mAb & {$[58]$} \\
\hline & PG16 bNAb & {$[59]$} \\
\hline & PGT121 bNAb & {$[60]$} \\
\hline & 3TC, TDF & [61] \\
\hline & AZT, ddl, IDV & {$[52]$} \\
\hline & FTC, RPV, DTG & {$[46,57]$} \\
\hline & FTC, TAF, EVG & {$[62]$} \\
\hline & FTC, TDF, DTG & {$[37,46,51,53,63]$} \\
\hline & FTC, TDF, RAL & {$[37,46,51,63]$} \\
\hline & FTC, TDF, RAL, 3B3(Fv)-PE38 immunotoxin & {$[64]$} \\
\hline & FTC, TDF, RAL, IFNa14 & {$[61,65]$} \\
\hline \multirow[t]{19}{*}{ Pre-exposure prophylaxis (PrEP) } & C5A peptide & {$[66]$} \\
\hline & Cc-griffithsin & {$[67]$} \\
\hline & CD4 Asics & {$[68]$} \\
\hline & CD4-expressing Lactobacillus acidophilus & {$[69]$} \\
\hline & CD4mc P-III-48 & {$[70]$} \\
\hline & DTG-ultra LA & [71] \\
\hline & EFdA & {$[72]$} \\
\hline & G2-S16 PCD & [73] \\
\hline & $\lg A$ & {$[74]$} \\
\hline & MVC & {$[75]$} \\
\hline & RAL-LA & {$[76]$} \\
\hline & RPV-LA & {$[39,77]$} \\
\hline & siCCR5 LFA-1 I-tsNP & [78] \\
\hline & TNV gel & [79-81] \\
\hline & VRC01 bNAb & {$[82]$} \\
\hline & FTC, TAF & [83] \\
\hline & FTC, TDF & {$[36,43,84,85]$} \\
\hline & TAF, EVG & {$[86]$} \\
\hline & b12, VRC01, VRC07 G54W bNAbs & {$[87]$} \\
\hline \multirow[t]{3}{*}{ Latency-reversing agents (LRAs) } & AZD5582 & {$[88]$} \\
\hline & panobinostat & {$[89]$} \\
\hline & SUW133 (bryostatin analog) & {$[90]$} \\
\hline \multirow[t]{2}{*}{ Vaccines } & PLGA-Gag microparticles & {$[49,91]$} \\
\hline & Recombinant GP140 683 & {$[49,91]$} \\
\hline Proviral excision & saCas9/sgRNA & {$[92]$} \\
\hline \multirow[t]{2}{*}{ T cell engineering } & CCR5 ShRNA & {$[93,94]$} \\
\hline & CD4 CAR & [95] \\
\hline
\end{tabular}

3TC, lamivudine; AsiCs, aptamer-siRNA chimeras; AZT, zidovudine; bNAb, broadly neutralizing antibody; CCR5, C-C chemokine receptor type 5; CAR, chimeric antigen receptor; CD4, cluster of differentiation 4; CD4mc, CD4 mimetic compound; Cc, Caulobacter crescentus recombinant expressing; dCA, didehydro-Cortistatin A; ddl, didanosine; DTG, dolutegravir; DTG-ultra LA, long acting dolutegravir; EFdA, 4'-ethynyl-2-fluoro-2'-deoxyadenosine; EVG, elvitegravir; FTC, emtricitabine; IDV, indinavir; IFNa14, interferon a suptype 14; IgA, immunoglobulin A; LFA-1 I-tsNP, lymphocyte function-associated antigen-1 integrin-targeted and stabilized nanoparticle; mAb, monoclonal antibody; MVC, maraviroc; PCD, polyanionic carbosilane dendrimers; PD-1, programmed cell death protein 1; PLGA, poly(lactic-co-glycolic) acid; RAL, raltegravir; RAL-LA, long-acting raltegravir; RPV, rilpivirine; RPV-LA, long acting rilpivirine; saCas9/sgRNA, Staphylococcus aureus CRISPR-associated protein 9/single-guide RNA; shRNA, short hairpin RNA; siCCR5, small interfering RNA CCR5; TAF, tenofovir alafenamide; TDF, tenofovir disoproxil fumarate; TNV; tenofovir 
strategy, is to incorporate the requisite human secondary lymphoid tissue (i.e. spleen) microenvironment for robust human immune cell (e.g. B cells, macrophages) development and response [5].

\section{Bone marrow-liver-thymus-spleen (BLTS)-humanized mouse model}

To address the limitations of the BLT-humanized mouse model, namely, poor development of secondary lymphoid tissue and modest macrophage reconstitution, we incorporated human spleen into the BLT-humanized mouse model, and termed these animals, Bone marrow-liverthymus-spleen (BLTS)-humanized mice [5] (Fig. 2). BLTS-humanized mice exhibit significant improvement over the BLT-humanized mice by addressing several limitations [5]. Successful spleen growth dramatically lowers the incidence of GvHD in BLTS-humanized mice, thus allowing for experimental studies that extend up to 9 months post-transplantation [5]. We speculate that the decreased GvHD in BLTS-humanized mice results from appropriate modulation of $\mathrm{T}$ cell activation by the human antigen-presenting cells in the human spleen xenograft. The human spleen in the BLTS-humanized mouse model recapitulates human adult spleen architecture and facilitates better reconstitution of immune cells, including human red pulp macrophages, which are poorly reconstituted in the BLT-humanized mouse model [5]. It is well established that macrophages can serve as a reservoir for HIV [106-108]; thus, the BLTS-humanized mouse model provides a system for investigating human splenic macrophage-HIV interactions [5]. Additionally, the spleen is a major lymphoid tissue reservoir, with $B$ cell follicles in the white-pulp serving as an immune privilege site for anti-HIV T-cells [109]. The human spleen in BLTShumanized mice provides a model for investigating antiHIV immune response within the white-pulp and the role of B cell follicle in mediating HIV persistence. The BLTS-humanized mouse model supports cART-mediated HIV load suppression, and replication competent HIV reservoirs can be detected in human spleen tissues [5]. Lymphoid tissue fibrosis is an immuno-pathogenic feature associated with HIV infection and plays a major role in mediating chronic inflammation and abrogating the development of a robust immune response [110]. A major advantage of the BLTS-humanized mouse model is that HIV infection results in lymphoid tissue fibrosis; this disease manifestation is absent in HIV-infected BLT-humanized mice [5]. Although the BLTS-humanized mouse model exhibits more robust immune reconstitution compared to its BLT counterpart, the two models share some limitations. The transplantation of the human tissues under the renal capsule requires an individual with advanced surgical skills. The BLTS-humanized mouse model uses human fetal tissues, which introduces logistical and operational constraints. The use of frozen fetal tissues and HSCs can alleviate some of those constraints (unpublished data). Demonstrating robust antiHIV immunity in HIS-humanized mouse models has been a long-term goal in the field because said system would allow robust evaluation of HIV vaccine candidates against circulating viral strains. The incorporation of human primary and secondary lymphoid tissues in HIShumanized mice brings us closer to this goal. At present, we are actively investigating the anti-HIV human immunity in the BLTS-humanized mouse model to determine if this system provides a means for evaluating HIV vaccines.

\section{Emerging human immune system (HIS)-humanized rat model}

Prior to the development of genetic engineering technologies for creating transgenic and knockout mice, rats were the predominant specie of rodents employed in biomedical research [6]. Advantages of using rats include their longer lifespans ( 3.5 years) and larger size $(\sim 350$ grams), which facilitates longer experimental window and larger sampling volumes compared to the short lifespan $(<1$ year $)$ and small size $(<25$ g) of mice [6]. Rats provide a more ideal platform for in vivo imaging of diseases, as the larger size of rats provides better resolution [111]. Additionally, rat models exhibit advanced cognitive skills and critical physiological parameters (e.g. heart rate, drug metabolism) that more closely mimic humans [112-115]. Recent advances in genetic engineering, such as the CRISPR/Cas 9 technology has enabled the development of several immunodeficient rat models for transplanting and regenerating human tissues and cells [7, 116-118]. Similar to currently used immunodeficient mouse models, immunodeficient rat models carry mutations in Rag1/2 and IL2ry genes, with or without SIRP1 $\alpha$ transgene $[7,116-118]$. A recent study demonstrated that these immunodeficient rats can be reconstituted with a myriad of human immune cells following transplantation with human-fetal liver-derived HSCs and autologous thymus tissues [7] (Fig. 2). These HIS-humanized rat models could provide a means for robust longitudinal studies on the safety and efficacy of therapeutic agents targeting the HIV reservoir. Additionally, HIS-humanized rats could provide a means for modeling HIV-associated end organ diseases, such as cardiovascular, neurocognitive and lung diseases.

\section{Conclusions}

Despite successful prevention of HIV transmission with antiviral drugs, it is likely that an effective vaccine provides the only means of ending the HIV epidemic [2]. 
Over the past decades, several promising vaccine candidates have failed in large-scale safety and efficacy clinical trials [2]. The failure of those clinical trials suggests that improved "gate keeper" animal modeling systems are needed for better prediction of vaccine candidate outcomes in human clinical trials [119]. Currently, the surrogate SIV-NHP model is the sole "gate keeper" animal model for determining potential of vaccine candidates [119]. Candidate HIV vaccines selected using this gatekeeper system have been unsuccessful in human clinical trials [119]; suggesting, major improvements in animal modeling are needed. Although significant advancements are still needed in improving HIS-humanized models, several recent advances, such as improved human-secondary lymphoid tissue development, along with the previously developed, robust primary lymphoid tissue development has made it possible to evaluate human immune responses to vaccines [5, 27]. Ideally, these "improved" HIS-humanized mouse models will complement NHP models in addressing critical gaps, such as vaccine-induced immune responses against circulating HIV strains, vaccine safety in the context of HIV transmission, and human-correlates of immunity. Although cART has significantly reduced the morbidity and mortality associated with chronic HIV infection, the HIV reservoir persists in people living with HIV (PLHIV) and is associated with chronic inflammation, lymphoid tissue damage, and a myriad of end-organ diseases [1]. Therefore, eradicating the HIV reservoir and associated chronic inflammation and end organ diseases remains a major challenge. The mechanisms of HIV persistence in PLHIV, despite robust cART-mediated suppression of the virus, are thought to be multifactorial. These factors include persistence in transcriptionally quiescent resting memory $\mathrm{CD} 4+\mathrm{T}$ cells in the peripheral blood and lymphoid tissues, infection of long-lived resident tissue macrophages in lymphoid tissues and immune privilege organs (e.g. brain, testes, B cell follicle, etc.), and dysregulation in anti-HIV immunity. By virtue of the multitude of factors that play a role in HIV persistence, in vivo models that recapitulate human host-HIV interactions are necessary for determining the safety and efficacy of therapeutic agents for eradicating HIV reservoirs. Improved HIS-humanized mouse models with systemic reconstitution of human immune cells and robust lymphoid tissues development provide a means of evaluating both directacting and immune-modulatory HIV-cure therapeutics. Further advances in improving the human-immune system in HIS-humanized mouse and rat models will provide better in vivo systems for evaluating the safety and efficacy of therapeutics and vaccines for HIV prevention and cure.

\section{Abbreviations}

HIV: Human immunodeficiency virus; CART: Combination antiretroviral therapy; HIS: Human immune system; PBMCs: Peripheral blood mononuclear cells; PBL: Peripheral blood lymphocytes; HSC: Human hematopoietic stem cells (HSC); GvHD: Graft-versus-host (GvHD); IV: Intravenous; IP: Intraperitoneal;

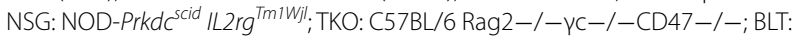
Bone marrow-Liver-Thymus; BLTS: Bone marrow-liver-thymus-Spleen.

\section{Acknowledgements \\ Not applicable. \\ Moses Turkle Bility is the senior author}

\section{Authors' contributions}

MTB conceived this review and contributed to the preparation of the manuscript. YA, CB, SB, IC, SH and KM contributed equally to the preparation of the manuscript. All authors read and approved the final manuscript.

\section{Funding}

This work was supported by the following NIH grants (R21OD024789, (National Institute of Allergy and Infectious Diseases) R21Al135412).

\section{Availability of data and materials \\ Not applicable.}

\section{Ethics approval}

The human fetal liver, spleen and thymus (gestational age of 18-20 weeks) used in the transplantations were obtained from medically or elective indicated termination of pregnancy through Magee-Women's Hospital of University of Pittsburgh Medical Center via the University of Pittsburgh, Health Sciences Tissue Bank. Written informed consent of the maternal donors was obtained in all cases, under IRB of the University of Pittsburgh guidelines and federal/state regulations. The use of human fetal organs/cells to construct humanized mice was reviewed by the University of Pittsburgh's IRB office, which has determined that this submission does not constitute human subject research as defined under federal regulations (45 CFR 46.102[d or f] and 21 CFR 56.102[c], [e], and [l]). The use of human hematopoietic stem cells was reviewed and approved by the Human Stem Cell Research Oversight (hSCRO) at the University of Pittsburgh. The use of biological agents (e.g., HIV), recombinant DNA, and transgenic animals was reviewed and approved by the Institutional Biosafety Committee (IBC) at the University of Pittsburgh. All animal studies were approved by the IACUC at the University of Pittsburgh and were conducted following $\mathrm{NIH}$ guidelines for housing and care of laboratory animals.

\section{Consent for publication}

Not applicable.

\section{Competing interests}

The authors declare that they have no competing interests.

\section{Author details}

${ }^{1}$ Department of Infectious Diseases and Microbiology, Graduate School of Public Health, University of Pittsburgh, Pittsburgh, PA, USA. ${ }^{2}$ Galveston National Laboratory and Department of Microbiology and Immunology, University of Texas Medical Branch, Galveston, TX, USA.

Received: 4 March 2020 Accepted: 31 March 2020

Published online: 10 April 2020

\section{References}

1. Ndung'u T, McCune JM, Deeks SG. Why and where an HIV cure is needed and how it might be achieved. Nature. 2019;576(7787):397-405.

2. Bekker LG, Tatoud R, Dabis F, Feinberg M, Kaleebu P, Marovich M, Ndung'u T, Russell N, Johnson J, Luba M, et al. The complex challenges of HIV vaccine development require renewed and expanded global commitment. Lancet. 2020;395(10221):384-8.

3. Akkina R, Barber DL, Bility MT, Bissig KD, Burwitz BJ, Eichelberg K, Endsley JJ, Garcia JV, Hafner R, Karakousis PC, et al. Small animal models 
for human immunodeficiency virus (HIV), hepatitis B, and tuberculosis: proceedings of an NIAID workshop. Curr HIV Res. 2019;18:19-28.

4. Allen TM, Brehm MA, Bridges S, Ferguson S, Kumar P, Mirochnitchenko O, Palucka K, Pelanda R, Sanders-Beer B, Shultz LD, et al. Humanized immune system mouse models: progress, challenges and opportunities. Nat Immunol. 2019;20(7):770-4.

5. Samal J, Kelly S, Na-Shatal A, Elhakiem A, Das A, Ding M, Sanyal A, Gupta P, Melody K, Roland B, et al. Human immunodeficiency virus infection induces lymphoid fibrosis in the BM-liver-thymus-spleen humanized mouse model. JCl Insight. 2018;3(18):e120430. https://doi.org/10.1172/ jci.insight. 120430.

6. Iannaccone PM, Jacob HJ. Rats! Disease models \& mechanisms. 2009:2(5-6):206-10

7. Yang X, Zhou J, He J, Liu J, Wang H, Liu Y, Jiang T, Zhang Q, Fu X, Xu Y. An immune system-modified rat model for human stem cell transplantation research. Stem Cell Reports. 2018;11(2):514-21.

8. Torbett BE, Picchio G, Mosier DE. hu-PBL-SCID mice: a model for human immune function, AIDS, and lymphomagenesis. Immunol Rev. 1991;124:139-64.

9. Kim KC, Choi BS, Kim KC, Park KH, Lee HJ, Cho YK, Kim SI, Kim SS, Oh YK, Kim YB. A simple mouse model for the study of human immunodeficiency virus. AIDS Res Hum Retroviruses. 2016;32(2):194-202.

10. Perdomo-Celis F, Medina-Moreno S, Heredia A, Davis H, Bryant J, Zapata JC. Chronic, acute, and reactivated HIV infection in humanized immunodeficient mouse models. J Vis Exp. 2019;154:e60315.

11. Safrit JT, Fung MSC, Andrews CA, Braun DG, Sun WNC, Chang TW, Koup RA. Hu-Pbl-Scid mice can be protected from Hiv-1 infection by passive transfer of monoclonal-antibody to the principal neutralizing determinant of envelope Gp120. Aids. 1993;7(1):15-21.

12. Metcalf Pate KA, Blankson JN. The mouse viral outgrowth assay: avatars for the detection of HIV-1 reservoirs. Retrovirology. 2017;14(1):52.

13. Perdomo-Celis F, Medina-Moreno S, Davis H, Bryant J, Taborda NA, Rugeles MT, Kottilil S, Zapata JC. High activation and skewed T cell differentiation are associated with low IL-17A levels in a hu-PBL-NSGSGM3 mouse model of HIV infection. Clin Exp Immunol. 2020. https:// doi.org/10.1111/cei.13416.

14. Ali N, Flutter B, Sanchez Rodriguez R, Sharif-Paghaleh E, Barber LD, Lombardi G, Nestle FO. Xenogeneic graft-versus-host-disease in NOD-scid IL-2Rgammanull mice display a T-effector memory phenotype. PLoS ONE. 2012:7(8):e44219.

15. Poluektova LY, Munn DH, Persidsky Y, Gendelman HE. Generation of cytotoxic $T$ cells against virus-infected human brain macrophages in a murine model of HIV-1 encephalitis. J Immunol. 2002;168(8):3941-9.

16. Brehm MA, Cuthbert A, Yang C, Miller DM, Dilorio P, Laning J, Burzenski L, Gott B, Foreman O, Kavirayani A, et al. Parameters for establishing humanized mouse models to study human immunity: analysis of human hematopoietic stem cell engraftment in three immunodeficient strains of mice bearing the IL2rgamma(null) mutation. Clin immunol. 2010;135(1):84-98.

17. Zhang L, Kovalev GI, Su L. HIV-1 infection and pathogenesis in a novel humanized mouse model. Blood. 2007;109(7):2978-81.

18. Cheng L, Ma J, Li G, Su L. Humanized Mice Engrafted With Human HSC Only or HSC and Thymus Support Comparable HIV-1 Replication, Immunopathology, and Responses to ART and Immune Therapy. Front Immunol. 2018;9:817.

19. Lepus CM, Gibson TF, Gerber SA, Kawikova I, Szczepanik M, Hossain J, Ablamunits V, Kirkiles-Smith N, Herold KC, Donis RO, et al. Comparison of human fetal liver, umbilical cord blood, and adult blood hematopoietic stem cell engraftment in NOD-scid/gammac-/-, Balb/c-Rag1-/gammac-/-, and CB-17-scid/bg immunodeficient mice. Hum Immunol. 2009;70(10):-802.

20. Hasgur S, Aryee KE, Shultz LD, Greiner DL, Brehm MA. Generation of Immunodeficient Mice Bearing Human Immune Systems by the Engraftment of Hematopoietic Stem Cells. Methods Mol Biol. 2016;1438:67-78.

21. Shultz LD, Brehm MA, Garcia-Martinez JV, Greiner DL. Humanized mice for immune system investigation: progress, promise and challenges. Nat Rev Immunol. 2012;12(11):786-98.

22. Pham TNQ, Meziane O, Miah MA, Volodina O, Colas C, Beland K, Li Y, Dallaire F, Keler T, Guimond JV, et al. Flt3L-mediated expansion of plasmacytoid dendritic cells Suppresses HIV infection in humanized mice. Cell Rep. 2019;29(9):2770-82.

23. Hofer U, Baenziger S, Heikenwalder M, Schlaepfer E, Gehre N, Regenass S, Brunner T, Speck RF. RAG2(-/-)gamma(-/-)(c) Mice transplanted with CD34(+) cells from human cord blood show low levels of intestinal engraftment and are resistant to rectal transmission of human immunodeficiency virus. J Virol. 2008;82(24):12145-53.

24. Berges BK, Akkina SR, Folkvord JM, Connick E, Akkina R. Mucosal transmission of R5 and X4 tropic HIV-1 via vaginal and rectal routes in humanized Rag2-/- gammac -/- (RAG-hu) mice. Virology. 2008;373(2):342-51.

25. Watanabe Y, Takahashi T, Okajima A, Shiokawa M, Ishii N, Katano I, Ito R, Ito M, Minegishi M, Minegishi N, et al. The analysis of the functions of human B and T cells in humanized NOD/shi-scid/gammac(null) (NOG) mice (hu-HSC NOG mice). Int Immunol. 2009;21 (7):843-58.

26. Shultz LD, Saito Y, Najima Y, Tanaka S, Ochi T, Tomizawa M, Doi T, Sone A, Suzuki N, Fujiwara H, et al. Generation of functional human T-cell subsets with HLA-restricted immune responses in HLA class I expressing NOD/SCID/IL2r gamma(null) humanized mice. Proc Natl Acad Sci USA. 2010;107(29):13022-7.

27. Li Y, Masse-Ranson G, Garcia Z, Bruel T, Kok A, Strick-Marchand H, Jouvion G, Serafini N, Lim Al, Dusseaux M, et al. A human immune system mouse model with robust lymph node development. Nat Methods. 2018;15(8):623-30.

28. Yu H, Borsotti C, Schickel JN, Zhu S, Strowig T, Eynon EE, Frleta D, Gurer C, Murphy AJ, Yancopoulos GD, et al. A novel humanized mouse model with significant improvement of class-switched, antigen-specific antibody production. Blood. 2017;129(8):959-69.

29. Rongvaux A, Willinger T, Martinek J, Strowig T, Gearty SV, Teichmann LL, Saito Y, Marches F, Halene S, Palucka AK, et al. Development and function of human innate immune cells in a humanized mouse model. Nat Biotechnol. 2014;32(4):364-72.

30. Billerbeck E, Barry WT, Mu K, Dorner M, Rice CM, Ploss A. Development of human CD4 + FoxP3 + regulatory T cells in human stem cell factor-, granulocyte-macrophage colony-stimulating factor-, and interleukin3-expressing NOD-SCID IL2Rgamma(null) humanized mice. Blood. 2011;117(11):3076-86.

31. Lan P, Tonomura N, Shimizu A, Wang SM, Yang YG. Reconstitution of a functional human immune system in immunodeficient mice through combined human fetal thymus/liver and CD34(+) cell transplantation. Blood. 2006;108(2):487-92.

32. Denton PW, Estes JD, Sun ZF, Othieno FA, Wei BDL, Wege AK, Powell DA Payne D, Haase AT, Garcia JV. Antiretroviral pre-exposure prophylaxis prevents vaginal transmission of HIV-1 in humanized BLT mice. Plos Med. 2008:5(1):79-89.

33. Melkus MW, Estes JD, Padgett-Thomas A, Gatlin J, Denton PW, Othieno FA, Wege AK, Haase AT, Garcia JV. Humanized mice mount specific adaptive and innate immune responses to EBV and TSST-1. Nat Med. 2006;12(11):1316-22

34. Aryee KE, Shultz LD, Brehm MA. Immunodeficient mouse model for human hematopoietic stem cell engraftment and immune system development. Methods Mol Biol. 2014;1 185:267-78.

35. Lavender KJ, Pang WW, Messer RJ, Duley AK, Race B, Phillips K, Scott D, Peterson KE, Chan CK, Dittmer U, et al. BLT-humanized C57BL/6 Rag2/-gammac-/-CD47-/- mice are resistant to GVHD and develop B- and T-cell immunity to HIV infection. Blood. 2013;122(25):4013-20.

36. Denton PW, Estes JD, Sun Z, Othieno FA, Wei BL, Wege AK, Powell DA, Payne D, Haase AT, Garcia JV. Antiretroviral pre-exposure prophylaxis prevents vaginal transmission of HIV-1 in humanized BLT mice. PLOS Med. 2008:5(1):e16.

37. Olesen R, Swanson MD, Kovarova M, Nochi T, Chateau M, Honeycutt JB, Long JM, Denton PW, Hudgens MG, Richardson A, et al. ART influences HIV persistence in the female reproductive tract and cervicovaginal secretions. J Clin Investig. 2016;126(3):892-904.

38. Hatziioannou T, Evans DT. Animal models for HIV/AIDS research. Nat Rev Microbiol. 2012;10(12):852-67.

39. Melody K, Roy CN, Kline C, Cottrell ML, Evans D, Shutt K, Pennings PS, Keele BF, Bility M, Kashuba ADM, et al. Long-acting rilpivirine (RPV) preexposure prophylaxis does not inhibit vaginal transmission of RPVresistant HIV-1 or select for high-frequency drug resistance in humanized mice. JVirol. 2020;94(8):e01912-19. 
40. Olesen R, Wahl A, Denton PW, Garcia JV. Immune reconstitution of the female reproductive tract of humanized BLT mice and their susceptibility to human immunodeficiency virus infection. J Reprod Immunol. 2011;88(2):195-203.

41. Stoddart CA, Maidji E, Galkina SA, Kosikova G, Rivera JM, Moreno ME, Sloan B, Joshi P, Long BR. Superior human leukocyte reconstitution and susceptibility to vaginal HIV transmission in humanized NOD-scid IL-2Rgamma(-/-) (NSG) BLT mice. Virology. 2011;417(1):154-60.

42. Sun Z, Denton PW, Estes JD, Othieno FA, Wei BL, Wege AK, Melkus MW, Padgett-Thomas A, Zupancic M, Haase AT, et al. Intrarectal transmission, systemic infection, and CD4 + T cell depletion in humanized mice infected with HIV-1. J Exp Med. 2007;204(4):705-14

43. Wahl A, Swanson MD, Nochi T, Olesen R, Denton PW, Chateau M, Garcia JV. Human breast milk and antiretrovirals dramatically reduce oral HIV-1 transmission in BLT humanized mice. PLoS Pathog. 2012;8(6):e1002732.

44. Hladik F, McElrath MJ. Setting the stage: host invasion by HIV. Nat Rev Immunol. 2008;8(6):447-57.

45. Asahchop EL, Meziane O, Mamik MK, Chan WF, Branton WG, Resch L, Gill MJ, Haddad E, Guimond JV, Wainberg MA, et al. Reduced antiretroviral drug efficacy and concentration in HIV-infected microglia contributes to viral persistence in brain. Retrovirology. 2017;14(1):47.

46. Honeycutt JB, Liao B, Nixon CC, Cleary RA, Thayer WO, Birath SL, Swanson MD, Sheridan P, Zakharova O, Prince F, et al. T cells establish and maintain CNS viral infection in HIV-infected humanized mice. J Clin Investig. 2018;128(7):2862-76.

47. Brainard DM, Seung E, Frahm N, Cariappa A, Bailey CC, Hart WK, Shin HS, Brooks SF, Knight HL, Eichbaum Q, et al. Induction of robust cellular and humoral virus-specific adaptive immune responses in human immunodeficiency virus-infected humanized BLT mice. J Virol. 2009;83(14):7305-21.

48. Long BR, Stoddart CA. Alpha interferon and HIV infection cause activation of human T cells in NSG-BLT mice. J Virol. 2012;86(6):3327-36.

49. Biswas S, Chang H, Sarkis PT, Fikrig E, Zhu Q, Marasco WA. Humora immune responses in humanized BLT mice immunized with West Nile virus and HIV-1 envelope proteins are largely mediated via human CD5 + B cells. Immunology. 2011;134(4):419-33.

50. DudekTE, No DC, Seung E, Vrbanac VD, Fadda L, Bhoumik P, Boutwell CL, Power KA, Gladden AD, Battis L, et al. Rapid evolution of HIV-1 to functional CD8 + T cell responses in humanized BLT Mice. Sci Transl Med. 2012;4(143):143198.

51. Denton PW, Olesen R, Choudhary SK, Archin NM, Wahl A, Swanson MD, Chateau M, Nochi T, Krisko JF, Spagnuolo RA, et al. Generation of HIV latency in humanized BLT mice. J Virol. 2012;86(1):630-4.

52. Marsden MD, Kovochich M, Suree N, Shimizu S, Mehta R, Cortado R, Bristol G, An DS, Zack JA. HIV latency in the humanized BLT mouse. J Virol. 2012;86(1):339-47.

53. Lavender KJ, Pace C, Sutter K, Messer RJ, Pouncey DL, Cummins NW, Natesampillai S, Zheng J, Goldsmith J, Widera M, et al. An advanced BLT-humanized mouse model for extended HIV-1 cure studies. Aids. 2018;32(1):1-10

54. Greenblatt MB, Vrbanac V, Tivey T, Tsang K, Tager AM, Aliprantis AO. Graft versus host disease in the bone marrow, liver and thymus humanized mouse model. PLOS ONE. 2012:7(9):e44664.

55. Covassin L, Jangalwe S, Jouvet N, Laning J, Burzenski L, Shultz LD, Brehm MA. Human immune system development and survival of nonobese diabetic (NOD)-scid IL2rgamma(null) (NSG) mice engrafted with human thymus and autologous haematopoietic stem cells. Clin Exp Immunol. 2013;174(3):372-88.

56. Kessing CF, Nixon CC, Li C, Tsai P, Takata H, Mousseau G, Ho PT, Honeycutt JB, Fallahi M, Trautmann L, et al. In vivo suppression of HIV rebound by Didehydro-Cortistatin A, a "Block-and-Lock" strategy for HIV-1 treatment. Cell Rep. 2017;21(3):600-11.

57. Shanmugasundaram U, Kovarova M, Ho PT, Schramm N, Wahl A, Parniak MA, Garcia JV. Efficient inhibition of HIV replication in the gastrointestinal and female reproductive tracts of humanized BLT mice by EFdA. 2016:11(7):e0159517.

58. Seung E, Dudek TE, Allen TM, Freeman GJ, Luster AD, Tager AM. PD-1 blockade in chronically HIV-1-infected humanized mice suppresses viral loads. PLoS ONE. 2013;8(10):e77780.

59. Stoddart CA, Galkina SA, Joshi P, Kosikova G, Long BR, Maidji E, Moreno ME, Rivera JM, Sanford UR, Sloan B, et al. Efficacy of broadly neutralizing monoclonal antibody PG16 in HIV-infected humanized mice. Virology. 2014;462-463:115-25.

60. Badamchi-Zadeh A, Tartaglia LJ, Abbink P, Bricault CA, Liu P-T, Boyd M, Kirilova M, Mercado NB, Nanayakkara OS, Vrbanac VD, et al. Therapeutic efficacy of vectored PGT121 gene delivery in HIV-1-infected humanized mice. J Virol. 2018;92:01925.

61. Li Q, Tso FY, Kang G, Lu W, Li Y, Fan W, Yuan Z, Destache CJ, Wood C. Early initiation of antiretroviral therapy can functionally control productive HIV-1 infection in humanized-BLT mice. J Acquir Immune Defic Syndr. 2015;69(5):519-27.

62. Mandal S, Kang G, Prathipati PK, Fan W, Li Q, Destache CJ. Long-acting parenteral combination antiretroviral loaded nano-drug delivery system to treat chronic HIV-1 infection: a humanized mouse model study. Antiviral Res. 2018;156:85-91.

63. Salgado M, Swanson MD, Pohlmeyer CW, Buckheit RW, Wu J, Archin NM, Williams TM, Margolis DM, Siliciano RF, Garcia JV, et al. HLA-B*57 Elite Suppressor and Chronic Progressor HIV-1 Isolates Replicate Vigorously and Cause CD4 + T Cell Depletion in Humanized BLT Mice. J Virol. 2014;88(6):3340-52.

64. Denton PW, Long JM, Wietgrefe SW, Sykes C, Spagnuolo RA, Snyder OD, Perkey K, Archin NM, Choudhary SK, Yang K, et al. Targeted cytotoxic therapy kills persisting HIV infected cells during ART. PLoS Pathog. 2014;10(1):e1003872.

65. Sutter K, Lavender KJ, Messer RJ, Widera M, Williams K, Race B, Hasenkrug KJ, Dittmer U. Concurrent administration of IFNa14 and CART in TKO-BLT mice enhances suppression of HIV-1 viremia but does not eliminate the latent reservoir. Sci Rep. 2019;9(1):1-6.

66. Gallay PA, Chatterji U, Kirchhoff A, Gandarilla A, Pyles RB, Baum MM, Moss JA. Protection efficacy of C5A against vaginal and rectal HIV challenges in humanized mice. Open Virol J. 2018;12(1):1-13.

67. Farr Zuend C, Nomellini JF, Smit J, Horwitz MS. A Caulobacter crescentus microbicide protects from vaginal infection with HIV1JR-CSF in humanized bone marrow-liver-thymus mice. J Virol. 2019;93(18):e00614-9.

68. Wheeler LA, Trifonova R, Vrbanac V, Basar E, McKernan S, Xu Z, Seung E, Deruaz M, Dudek T, Einarsson Jl, et al. Inhibition of HIV transmission in human cervicovaginal explants and humanized mice using CD4 aptamer-siRNA chimeras. J Clin Investig. 2011;121(6):2401-12.

69. Wei W, Wiggins J, Hu D, Vrbanac V, Bowder D, Mellon M, Tager A, Sodroski J, Xiang S-H. Blocking HIV-1 infection by chromosomal integrative expression of human CD4 on the surface of Lactobacillus acidophilus ATCC 4356. J Virol. 2019:93(8):1830.

70. Princiotto AM, Vrbanac VD, Melillo B, Park J, Tager AM, Smith AB 3rd, Sodroski J, Madani N. A small-molecule CD4-Mimetic compound protects bone marrow-liver-thymus humanized mice from HIV-1 infection. J Infect Dis. 2018;218(3):471-5.

71. Kovarova M, Benhabbour SR, Massud I, Spagnuolo RA, Skinner B, Baker CE, Sykes C, Mollan KR, Kashuba ADM, García-Lerma JG, et al. Ultra-longacting removable drug delivery system for HIV treatment and prevention. Nat Commun. 2018;9(1):1-1.

72. Kovarova M, Shanmugasundaram U, Baker CE, Spagnuolo RA, De C, Nixon CC, Wahl A, Garcia JV. HIV pre-exposure prophylaxis for women and infants prevents vaginal and oral HIV transmission in a preclinical model of HIV infection. J Antimicrob Chemother. 2016;71(11):3185-94.

73. Sepúlveda-Crespo D, Serramía MJ, Tager AM, Vrbanac V, Gómez R, Mata FJ, Jiménez JL, Muñoz-Fernández MÁ. Prevention vaginally of HIV-1 transmission in humanized BLT mice and mode of antiviral action of polyanionic carbosilane dendrimer. Nanomedicine. 2015;11(6):1299-308.

74. Hur EM, Patel SN, Shimizu S, Rao DS, Gnanapragasam PN, An DS, Yang L, Baltimore D. Inhibitory effect of HIV-specific neutralizing IgA on mucosal transmission of HIV in humanized mice. Blood. 2012;120(23):4571-82

75. Council OD, Swanson MD, Spagnuolo RA, Wahl A, Garcia JV. Role of semen on vaginal HIV-1 transmission and maraviroc protection. Antimicrob Agents Chemother. 2015;59(12):7847-51.

76. Kovarova M, Swanson MD, Sanchez RI, Baker CE, Steve J, Spagnuolo RA, Howell BJ, Hazuda DJ, Garcia JV. A long-acting formulation of the integrase inhibitor raltegravir protects humanized BLT mice from repeated high-dose vaginal HIV challenges. J Antimicrobial chemotherapy. 2016:71(6):1586-96. 
77. Kovarova M, Council OD, Date AA, Long JM, Nochi T, Belshan M, Shibata A, Vincent $\mathrm{H}$, Baker CE, Thayer WO, et al. Nanoformulations of rilpivirine for topical pericoital and systemic coitus-independent administration efficiently prevent HIV transmission. PLoS Pathog. 2015;11(8):e1005075.

78. Kim SS, Peer D, Kumar P, Subramanya S, Wu H, Asthana D, Habiro K, Yang YG, Manjunath N, Shimaoka M, et al. RNAi-mediated CCR5 silencing by LFA-1-targeted nanoparticles prevents HIV infection in BLT mice. Mol Ther. 2010;18(2):370-6.

79. Chateau ML, Denton PW, Swanson MD, McGowan I, Garcia JV. Rectal transmission of transmitted/founder HIV-1 is efficiently prevented by topical $1 \%$ tenofovir in BLT humanized mice. PLoS ONE. 2013;8(3):e60024

80. Denton PW, Othieno F, Martinez-Torres F, Zou W, Krisko JF, Fleming E, Zein S, Powell DA, Wahl A, Kwak YT, et al. One percent tenofovir applied topically to humanized BLT mice and used according to the CAPRISA 004 experimental design demonstrates partial protection from vaginal HIV infection, validating the BLT model for evaluation of new microbicide candidates. J Virol. 2011;85(15):7582-93.

81. Destache CJ, Mandal S, Yuan Z, Kang G, Date AA, Lu W, Shibata A, Pham $R$, Bruck P, Rezich M, et al. Topical tenofovir disoproxil fumarate nanoparticles prevent HIV-1 vaginal transmission in a humanized Mouse model. Antimicrob Agents Chemother. 2016;60(6):3633-9.

82. Sun M, Li Y, Yuan Z, Lu W, Kang G, Fan W, Li Q. VRC01 antibody protects against vaginal and rectal transmission of human immunodeficiency virus 1 in hu-BLT mice. Adv Virol. 2016:161(9):2449-55.

83. Mandal S, Kang G, Prathipati PK, Zhou Y, Fan W, Li Q, Destache CJ. Nanoencapsulation introduces long-acting phenomenon to tenofovir alafenamide and emtricitabine drug combination: a comparative preexposure prophylaxis efficacy study against HIV-1 vaginal transmission. J Control Release. 2019;294:216-25.

84. Gallay PA, Chatterji U, Kirchhoff A, Gandarilla A, Gunawardana M, Pyles RB, Marzinke MA, Moss JA, Baum MM. Prevention of vaginal and rectal HIV transmission by antiretroviral combinations in humanized mice. PLoS ONE. 2017;12(9):e0184303.

85. Denton PW, Krisko JF, Powell DA, Mathias M, Kwak YT, Martinez-Torres F, Zou W, Payne DA, Estes JD, Garcia JV. Systemic administration of antiretrovirals prior to exposure prevents rectal and intravenous HIV-1 transmission in humanized BLT mice. PLoS ONE. 2010;5(1):e8829.

86. Mandal S, Prathipati PK, Kang G, Zhou Y, Yuan Z, Fan W, Li Q, Destache CJ. Tenofovir alafenamide and elvitegravir loaded nanoparticles for long-acting prevention of HIV-1 vaginal transmission. AIDS. 2017;31(4):469-76.

87. Balazs AB, Ouyang Y, Hong CM, Chen J, Nguyen SM, Rao DS, An DS, Baltimore D. Vectored immunoprophylaxis protects humanized mice from mucosal HIV transmission. Nat Med. 2014;20(3):296-300.

88. Nixon CC, Mavigner M, Sampey GC, Brooks AD, Spagnuolo RA, Irlbeck DM, Mattingly C, Ho PT, Schoof N, Cammon CG, et al. Systemic HIV and SIV latency reversal via non-canonical NF-kappaB signalling in vivo. Nature. 2020:578:160-5.

89. Tsai P, Wu G, Baker CE, Thayer WO, Spagnuolo RA, Sanchez R, Barrett S, Howell B, Margolis D, Hazuda DJ, et al. In vivo analysis of the effect of panobinostat on cell-associated HIV RNA and DNA levels and latent HIV infection. Retrovirology. 2016:13(1):36.

90. Marsden MD, Loy BA, Wu X, Ramirez CM, Schrier AJ, Murray D, Shimizu A, Ryckbosch SM, Near KE, Chun TW, et al. In vivo activation of latent HIV with a synthetic bryostatin analog effects both latent cell "kick" and "kill" in strategy for virus eradication. PLoS Pathog. 2017;13(9):e1006575.

91. Claiborne DT, Dudek TE, Maldini CR, Power KA, Ghebremichael M, Seung E, Mellors EF, Vrbanac VD, Krupp K, Bisesi A, et al. Immunization of BLT humanized mice redirects T cell responses to Gag and reduces acute HIV-1 viremia. J Virol. 2019;93:e00814-9.

92. Yin C, Zhang T, Qu X, Zhang Y, Putatunda R, Xiao X, Li F, Xiao W, Zhao H, Dai $S$, et al. In vivo excision of HIV-1 provirus by saCas9 and multiplex single-guide RNAs in animal models. Mol Ther. 2017;25:1168-86.

93. Shimizu S, Hong P, Arumugam B, Pokomo L, Boyer J, Koizumi N, Kittipongdaja P, Chen A, Bristol G, Galic Z, et al. A highly efficient short hairpin RNA potently down-regulates CCR5 expression in systemic lymphoid organs in the hu-BLT mouse model. Blood. 2010;115(8):1534-44.

94. Ringpis GE, Shimizu S, Arokium H, Camba-Colon J, Carroll MV, Cortado R, Xie Y, Kim PY, Sahakyan A, Lowe EL, et al. Engineering HIV-1-resistant
T-cells from short-hairpin RNA-expressing hematopoietic stem/progenitor cells in humanized BLT mice. PLOS ONE. 2012;7(12):e53492.

95. Zhen A, Rezek V, Youn C, Rick J, Lam B, Chang N, Zack J, Kamata M, Kitchen S. Stem-cell based engineered immunity against HIV infection in the humanized mouse model. J Vis Exp. 2016. https://doi. org/10.3791/54048

96. Brown ME, Zhou Y, Mclntosh BE, Norman IG, Lou HE, Biermann M, SulIivan JA, Kamp TJ, Thomson JA, Anagnostopoulos PV, et al. A humanized mouse model generated using surplus neonatal tissue. Stem Cell Rep. 2018;10(4):1175-83

97. Nochi T, Denton PW, Wahl A, Garcia JV. Cryptopatches are essential for the development of human GALT. Cell reports. 2013;3(6):1874-84.

98. Brehm MA, Wiles MV, Greiner DL, Shultz LD. Generation of improved humanized mouse models for human infectious diseases. J Immunol Methods. 2014;410:3-17.

99. Vuyyuru R, Patton J, Manser T. Human immune system mice: current potential and limitations for translational research on human antibody responses. 2011;51(2-3):257-66.

100. Cao X, Shores EW, Hu-Li J, Anver MR, Kelsail BL, Russell SM, Drago J, Noguchi M, Grinberg A, Bloom ET, et al. Defective lymphoid development in mice lacking expression of the common cytokine receptor $\gamma$ chain. Immunity. 1995;2(3):223-38.

101. Rajesh D, Zhou Y, Jankowska-Gan E, Roenneburg DA, Dart ML, Torrealba J, Burlingham WJ. Th1 and Th17 immunocompetence in humanized NOD/SCID/IL2rynull mice. Hum Immunol. 2010;71(6):551-9.

102. Watanabe Y, Takahashi T, Okajima A, Shiokawa M, Ishii N, Katano I, Ito $\mathrm{R}$, Ito M, Minegishi M, Minegishi $\mathrm{N}$, et al. The analysis of the functions of human B and T cells in humanized NOD/shi-scid/ cnull (NOG) mice (hu-HSC NOG mice). Hum Immunol. 2009;21(7):843-58.

103. Martinez-Torres F, Nochi T, Wahl A, Garcia JV, Denton PW. Hypogammaglobulinemia in BLT humanized mice - an animal model of primary antibody deficiency. PLOS ONE. 2014;9(10):e108663.

104. Jangalwe S, Shultz LD, Mathew A, Brehm MA. Improved B cell development in humanized NOD-scid IL2Rgamma(null) mice transgenically expressing human stem cell factor, granulocyte-macrophage colony-stimulating factor and interleukin-3. Immun Inflamm Dis. 2016:4(4):427-40.

105. Takahashi T, Katano I, Ito R, Goto M, Abe H, Mizuno S, Kawai K, Sugiyama F, Ito M. Enhanced antibody responses in a Novel NOG transgenic mouse with restored lymph node organogenesis. Front Immunol. 2017;2018:8.

106. Wong ME, Jaworowski A, Hearps AC. The HIV reservoir in monocytes and macrophages. Front Immunol. 2019;10:1435.

107. Ganor Y, Real F, Sennepin A, Dutertre CA, Prevedel L, Xu L, Tudor D, Charmeteau B, Couedel-Courteille A, Marion S, et al. HIV-1 reservoirs in urethral macrophages of patients under suppressive antiretroviral therapy. Nat Microbiol. 2019;4(4):633-44.

108. Honeycutt JB, Wahl A, Baker C, Spagnuolo RA, Foster J, Zakharova O, Wietgrefe S, Caro-Vegas C, Madden V, Sharpe G, et al. Macrophages sustain HIV replication in vivo independently of T cells. J Clin Invest. 2016;126(4):1353-66.

109. Bronnimann MP, Skinner PJ, Connick E. The B-Cell Follicle in HIV Infection: barrier to a Cure. Front Immunol. 2018:9:20.

110. Kityo C, Makamdop KN, Rothenberger M, Chipman JG, Hoskuldsson T, Beilman GJ, Grzywacz B, Mugyenyi P, Ssali F, Akondy RS, et al. Lymphoid tissue fibrosis is associated with impaired vaccine responses. J Clin Invest. 2018;128(7):2763-73.

111. Febo M. Technical and conceptual considerations for performing and interpreting functional MRI studies in awake rats. Front Psychiatry. 2011:2:43.

112. Ellenbroek B, Youn J. Rodent models in neuroscience research: is it a rat race? Dis Model Mech. 2016;9(10):1079-87.

113. Bader M. Rat models of cardiovascular diseases. Methods Mol Biol. 2010:597:403-14.

114. Storch MK, Stefferl A, Brehm U, Weissert R, Wallstrom E, Kerschensteiner $\mathrm{M}$, Olsson T, Linington $\mathrm{C}$, Lassmann $\mathrm{H}$. Autoimmunity to myelin oligodendrocyte glycoprotein in rats mimics the spectrum of multiple sclerosis pathology. Brain Pathol. 1998;8(4):681-94.

115. Zaragoza C, Gomez-Guerrero C, Martin-Ventura JL, Blanco-Colio L, Lavin B, Mallavia B, Tarin C, Mas S, Ortiz A, Egido J. Animal models of cardiovascular diseases. J Biomed Biotechnol. 2011;2011:497841. 
116. He D, Zhang J, Wu W, Yi N, He W, Lu P, Li B, Yang N, Wang D, Xue Z, et al. A novel immunodeficient rat model supports human lung cancer xenografts. FASEB J. 2019;33(1):140-50.

117. Beldick SR, Hong J, Altamentova S, Khazaei M, Hundal A, Zavvarian MM, Rumajogee P, Chio J, Fehlings MG. Severe-combined immunodeficient rats can be used to generate a model of perinatal hypoxic-ischemic brain injury to facilitate studies of engrafted human neural stem cells. PLoS ONE. 2018;13(11):e0208105.

118. Noto FK, Adjan-Steffey V, Tong M, Ravichandran K, Zhang W, Arey A, McClain CB, Ostertag E, Mazhar S, Sangodkar J, et al. Sprague Dawley Rag2-Null rats created from engineered spermatogonial stem cells are immunodeficient and permissive to human xenografts. Mol Cancer Ther. 2018;17(11):2481-9.

119. Shedlock DJ, Silvestri G, Weiner DB. Monkeying around with HIV vaccines: using rhesus macaques to define 'gatekeepers' for clinical trials. Nat Rev Immunol. 2009;9(10):717-28.

\section{Publisher's Note}

Springer Nature remains neutral with regard to jurisdictional claims in published maps and institutional affiliations.
Ready to submit your research? Choose BMC and benefit from:

- fast, convenient online submission

- thorough peer review by experienced researchers in your field

- rapid publication on acceptance

- support for research data, including large and complex data types

- gold Open Access which fosters wider collaboration and increased citations

- maximum visibility for your research: over 100M website views per year

At BMC, research is always in progress.

Learn more biomedcentral.com/submissions 